\title{
Pengaruh Keterampilan Sosial terhadap Komitmen Organisasi Pengurus UKK-KOPMA UIN Antasari Banjarmasin
}

\author{
Muhammad Hasan Amin, Ahmad Suriadi dan Shanty Komalasari \\ Universitas Islam Negeri (UIN) Antasari Banjarmasin
}

\begin{abstract}
Organization is a group formed in order to achieve specified goals. This goal can be achieved if the management in it has a good organizational commitment. There are several factors that influence a person in increasing his organizational commitment. One of them is a factor in him, namely in the form of social skills. So the existence of this study aims to determine the effect of social skills on organizational commitment UKK-KOPMA UIN Antasari Banjarmasin. The hypothesis proposed in this study is that there is a significant positive effect between social skills and organizational commitment. This research is quantitative with purposive sample sampling technique. The research data collection instrument used a Likert scale model and data analysis used simple linear regression analysis with the help of SPSS. The results of this study indicate that the significant value of the influence of social skills on organizational commitment is 0.048 lower than the significant standard, namely $0.05(0.048<0.05)$, which means that there is an influence between social skills and organizational commitment of the UKK-KOPMA management at UIN Antasari Banjarmasin for the period 2018/2019. . Then, the R square value is 0.096, which means that the social skills variable has an influence on organizational commitment by $9.6 \%$ and the rest is influenced by other factors.
\end{abstract}

Keywords: Social skills; organizational commitment; management of UKK-KOPMA

\begin{abstract}
Abstrak
Organisasi adalah suatu kelompok yang dibentuk guna mencapai tujuan yang ditentuan. Tujuan tersebut bisa tercapai apabila pengurus di dalamnya memiliki komitmen organisasi yang bagus. Ada beberapa faktor yang mempengaruhi seseorang dalam meningkatkan komitmen organisasinya. Salah satunya adalah faktor dalam dirinya, yaitu berupa keteram pilan sosial. Maka adanya penelitian ini bertujuan untuk mengetahui pengaruh keterampilan sosial terhadap komitmen organisasi UKK-KOPMA UIN Antasari Banjarmasin. Hipotesis yang diajukan pada penelitian ini adalah terdapat pengaruh positif yang signifikan antara keterampilan sosial dengan komitmen organisasi. Penelitian ini bersifat kuantitatif dengan teknik pengambilan sampel Purposive Sampling. Instrumen pengumpulan data penelitian ini menggunakan Skala model Likert dan analisis data menggunakan analisis regresi linear sederhana dengan bantuan SPSS. Hasil penelitian ini menunjukkan bahwa nilai signifikan dari pengaruh keterampilan sosial terhadap komitmen organisasi adalah 0.048 lebih rendah dari standar signifikan, yaitu $0.05(0.048<0.05)$ yang artinya terdapat pengaruh antara keterampilan sosial terhadap komitmen organisasi pengurus UKK-KOPMA UIN Antasari Banjarmasin periode 2018/2019. Kemudian, nilai R square 0.096 yang artinya variabel keterampilan sosial
\end{abstract}


memiliki pengaruh terhadap komitmen organisasi sebesar 9.6\% dan sisanya dipengaruhi oleh faktor lain.

Kata kunci: Keterampilan sosial; komitmen organisasi; pengurus UKK-KOPMA

Mahasiswa adalah individu yang terdaftar secara resmi di akademi yang berusia sekitar 18-30 tahun. Mahasiswa dididik untuk menjadi seorang intelektual yang berguna bagi masyarakat sekitarnya (Kurniawati, 2016). Sebagai agen perubahan, mahasiswa diharapkan mampu untuk mengembangkan atau menjadikan masyarakat lebih maju dengan keilmuan yang dimiliki seiring perkembangan zaman. Oleh karena itu, tidak hanya menuntut ilmu di dalam kelas, mahasiswa juga dianjurkan untuk mengikuti ekstrakurikuler yang disediakan oleh akademi tersebut.

Ekstrakurikuler yang ada di akademi atau perguruan tinggi adalah organisasi. Organisasi adalah suatu kelompok yang dibentuk guna mencapai tujuan yang ditentukan. Mooney berpendapat bahwa organisasi itu adalah sebuah wadah yang berisikan orang-orang yang ingin mencapai tujuan bersama (Asmuni, 2018). Individu yang tergabung dalam sebuah organisasi, akan merumuskan tugas-tugas atau capaian-capaian yang dikerjakan oleh anggota dan kepengurusannya untuk mencapai tujuan organisasi tersebut. Anggota dan pengurus harus memiliki tingkat solidaritas yang baik agar tugas-tugas yang diemban, dapat terlaksana dengan baik menurut aturan yang dibuat. Oleh sebab itu, dalam sebuah organisasi dibutuhkan komitmen yang tinggi agar mampu berjalan dengan baik dan destinasi bisa tercapai.

Komitmen dalam organisasi adalah kesetiaan seseorang untuk tetap berada dalam organisasi tersebut. Melaksanakan tanggung jawab dengan baik dan memberikan kualitas diri yang maksimal kepada organisasi. Mowday mengatakan bahwa komitmen organisasi itu adalah keterlibatan anggotanya untuk selalu setia terhadap organisasi, melaksanakan tugas menurut nilai dan tujuan organisasi dan hasrat yang kuat dalam mempertahankan identitas keorganisasian (Ghoniyah, 2011). Meyer dan Allen menyebutkan ada 3 komponen yang harus dicapai seseorang agar mendapatkan komitmen yang tinggi terhadap organisasinya. Komponen itu adalah normative commitment, affective commitment dan continuance commitment (Sutanto \& Gunawan, 2013). Nursyamsi mengatakan dalam penelitiannya bahwa komitmen 
organisasi itu menimbulkan loyalitas anggotanya kepada organisasi. Srimulyani juga berpendapat bahwa orang yang memiliki komitmen organisasi akan memiliki keterikatan emosional terhadap organisasinya, menimbulkan rasa terima kasih yang besar terhadap organisasi sehingga dia merasa berkewajiban untuk memberikan balasan atas apa yang organisasi berikan dan berkeinginan tetap berada di organisasi karena capaian yang dia berikan terhadap organisasi belum maksimal (Kurniawan, 2015).

Selain itu, dalam sebuah organisasi bergaul antar individu sudah pasti terjadi, karena organisasi merupakan wadah dari beberapa individu yang memiliki tujuan sama. Pada saat bergaul, seseorang harus menempatkan dirinya pada tempat yang benar. Jika menjadi ketua, maka harus mengerti bagaimana cara bergaul dengan bawahan begitu pula sebaliknya.

Jika ingin menciptakan pergaulan yang baik, maka seseorang perlu melatih keterampilan sosialnya. Keterampilan sosial yaitu kemahiran dalam berinteraksi dengan orang lain sekaligus mendapatkan keuntungan untuk diri sendiri. Menurut Combs dan Slaby, keterampilan sosial adalah keahlian menjalin hubungan dengan orang lain menggunakan metode khusus yang mampu diterima oleh lingkungan dan menguntungkan juga untuk dirinya sendiri (Machmud, 2013). Jika keterampilan sosial seseorang itu bagus, maka akan mudah untuk beradaptasi dengan lingkungan.

Menurut Schneider dkk. Ciri seseorang memiliki keteram pilan sosial yang baik adalah memahami emosi, tujuan dan pikiran lawan bicara, menanggapi dan mengadaptasi informasi dari hasil interaksi dengan baik dan sesuai dengan yang dimaksudkan. Mampu mengawali pembicaraan atau interaksi dengan orang, mendengarkan kemudian mengakhirinya dengan baik. Mengetahui akibat dari tindakan sosial yang terjadi, baik untuk dirinya, orang lain atau tujuan yang dicapainya, mengolah penilaian moral mendalam yang berguna bagi lingkungan sosial, memiliki sikap serius dan perhatian terhadap kepentingan orang lain, dapat mengeluarkan emosi positif dan negatif dengan akurat, dapat menahan perilaku yang tidak baik ketika ada pikiran dan perasaan negatif terhadap orang lain, dapat berkomunikasi verbal maupun non-verbal yang dapat dipahami terhadap lawan bicara, mem perhatikan dan berusaha memenuhi permintaan orang lain (Widyastuti, 2011). Individu yang mempunyai keterampilan sosial yang bagus akan bisa membangun keakraban dengan individu lainnya dan merasakan 
manfaatnya sehingga terbangun pula kepercayaan antarsesama, mampu menghargai dan bisa berkomunikasi dengan baik terhadap individu lainnya.

Pada organisasi yang berlandaskan keislaman, keterampilan sosial dan komitmen organisasi juga dibahas dalam Alquran. Keterampilan sosial terdapat dalam Q. S. al-Hujurat/49: 13 yang artinya:

"Wahai manusia! Sungguh, Kami telah menciptakan kamu dari seorang laki-laki dan seorang perempuan, kemudian Kami jadikan kamu berbangsa-bangsa dan bersuku-suku agar kamu saling mengenal. Sungguh, yang paling mulia di antara kamu di sisi Allah ialah orang yang paling bertakwa. Sungguh, Allah Maha Mengetahui, Mahateliti.,

Sedangkan, komitmen organisasi terdapat pada Q.S. al-Hijr/15: 99 yang artinya,

"Dan sembahlah Tuhanmu sampai yakin (ajal) datang kepadamu."

Ayat yang pertama menjelaskan bahwa setiap manusia yang diciptakan dari berbagai macam suku dan bangsa harus saling mengenal. Saling mengenal satu sama lain. Hal ini diperlukan untuk mencapai satu tujuan, yaitu mendapatkan kebahagiaan dunia dan akhirat. Kebahagiaan itu dicapai dengan cara bertaqwa kepada Allah SWT. Begitu pula dalam sebuah organisasi, untuk mencapai tujuan bersama, saling mengenal itu diperlukan bagi anggota, pengurus maupun pemimpin. Hal tersebut merupakan keterampilan sosial.

Pada ayat kedua, beribadah kepada Allah SWT itu dilakukan secara terus menerus sampai ajal menjemput. Beribadah ini merupakan gambaran dari ketaqwaan kepada Allah SWT. Konsistensi dalam ketaqwaan kepada Allah SWT ini disebut sebagai komitmen. Orang yang berkomitmen adalah orang yang melakukan sesuatu secara terus-menerus sebagaimana pendapat Meyer dan Allen di atas. Komitmen ini merupakan tanggung jawab sebagai hamba Allah SWT untuk mencapai kebahagiaan yang dijanjikan oleh Allah SWT. Begitu pula dalam organisasi, tugas dan kewajiban harus dilaksanakan sampai tuntas agar organisasi tetap berdiri dan terus berjalan.

Menurut ayat-ayat di atas, keterampilan sosial merupakan suatu hal yang dapat membantu individu dalam berkomitmen terhadap organisasi. Keterampilan sosial yang dijelaskan oleh ayat di atas memiliki manfaat untuk memudahkan individu dalam melaksanakan tugas secara terus-menerus. Sedangkan komitmen organisasi memberikan 
manfaat agar individu sadar akan tanggung jawab yang diberikan oleh organisasi dan senantiasa melaksanakannya.

Pada penelitian ini, peneliti ingin membuktikan secara empiris, apakah keterampilan sosial berpengaruh terhadap tingkat komitmen organisasi. Subjek penelitian ini, yaitu pengurus organisasi Unit Kegiatan Khusus Koperasi Mahasiswa Universitas Islam Negeri Antasari Banjarmasin (UKK-KOPMA UIN Antasari Banjarmasin). Menurut hasil wawancara pada tanggal 18 Februari 2019, jumlah anggota kepengurusan sebanyak 37 pengurus pada periode 2018/2019 kemudian jumlah pengurus meningkat menjadi 101 pengurus. Dinamika peningkatan jumlah pengurus yang terjadi, membuat peneliti ingin meneliti organisasi ini dan menjadikan pengurus di dalamnya sebagai subjek.

Menurut uraian di atas, untuk membuktikan secara empiris bahwa keteram pilan sosial memiliki pengaruh terhadap tingkat komitmen organisasi, peneliti membuat penelitian dengan judul "Pengaruh Keterampilan Sosial terhadap Komitmen Organisasi pada Pengurus Organisasi UKK-KOPMA UIN Antasari Banjarmasin".

\section{Metode}

Metode penelitian yang digunakan adalah penelitian kuantitatif dengan jenis penelitian lapangan atau field research. Seperti yang sudah tertera dari judul subjek pada penelitian ini adalah Pengurus UKK-KOPMA UIN Antasari Banjarmasin periode 2018/2019 yang memiliki total jumlah 101 orang, Teknik atau cara yang digunakan untuk memperoleh sampel yaitu dengan metode Purposive Sampling, dilakukan melalui pengambilan subjek yang bukan berdasar atas strata ataupun random, melainkan didasari dengan tujuan yang ditentukan (Sugiyono, 2015). Artinya, terdapat kriteria tertentu dalam pemilihan sampel. Kriteria sampel pada penelitian ini adalah pengurus organisasi UKK-KOPMA yang bersedia untuk menjadi subjek sebanyak 41 responden. Laki-laki berjumlah 15 responden dan perempuan sebanyak 26 responden.

Pengumpulan data di penelitian ini terdapat 2 skala yaitu skala keterampilan sosial dan skala komitmen organisasi. Skala keterampilan sosial dalam penelitian ini disusun berdasarkan aspek dari teori Daniel Goleman, yaitu mengatur kelompok, merundingkan penyelesaian, 
hubungan individu, dan analisis sosial (Goleman, 2019). Pada skala komitmen organisasi disusun berdasarkan aspek dari teori Allen, Mayer dan Smith, yaitu komitmen afektif, komitmen kontinuan dan komitmen normatif (Setiawan, 2011).

Analisis data pada penelitian ini menggunakan teknik analisis statistik. Statistik diproses melalui tahapan mulai dari mengumpulkan atau mencari data, penyusunan data, menyajikan, dan menganalisa serta penyelidikan yang berupa penyajian angka-angka. Adanya alasan lain dari statistik yang merupakan dasar sifatnya objektif dan bersifat universal yang itu artinya statistik mampu berada pada setiap bidang ilmu penelitian untuk diterapkan. Adapun suatu teknik atau cara yang digunakan untuk melakukan pengujian hipotesis adalah dengan teknik analisis linear sederhana yang bernama linear regression (salah satu teknik uji yang ada dalam aplikasi SPSS).

\section{H a s i 1}

\section{Uji Asumsi}

Hasil uji normalitas dengan nilai signifikan shapiro-wilk adalah 0.052 pada variabel keterampilan sosial. Nilai ini melebihi nilai standar signifikan 0.05 (0.052>0.05). Pada bagian komitmen organisasi, nilai signifikannya 0.325 . Nilai itu juga melebihi 0.05 yang merupakan nilai standar signifikan $(0.325>0.05)$. Hasil itu memberitahukan bahwa variabel keterampilan sosial dan variabel komitmen organisasi adalah normal pada distribusinya. Pada uji linearitas kedua variabel tersebut mendapatkan nilai signifikan deviation from linearity 0.106 . Nilai ini melebihi nilai standar signifikan 0.05 . Dapat diartikan bahwa sebaran titik pada 2 variabel dalam penelitian ini memiliki hubungan yang linear.

\section{Uji Hipotesis}

Hasil analisis untuk uji hipotesis melalui teknik linear regression diperoleh hasil signifikan $0.048<0.05$ dan nilai koefisien regresi sebesar 0.347 artinya variabel keterampilan sosial memiliki pengaruh positif yang signifikan terhadap variabel komitmen organisasi pengurus UKK-KOPMA UIN Antasari Banjarmasin periode 2018/2019. Berikut tabel di bawah ini agar lebih jelasnya untuk melihat nilai regresi/pengaruh variabel keterampilan sosial terhadap komitmen organisasi: 
Tabel 1

Linear Regression

\begin{tabular}{ccccc}
\hline Model & $\mathrm{R}$ & $\mathrm{R}$ Square & Adjusted R Square & Std. Error of the Estimate \\
\hline 1 & .311 &, 096 &, 073 & 6,168 \\
\hline
\end{tabular}

Pada tabel 1 di atas diketahui bahwa nilai koefisien determinan ( $R$ square) sebesar 0,096 pengaruh variabel bebas (keterampilan sosial) terhadap variabel terikat (komitmen organisasi) ialah $9.6 \%$. sedangkan nilai $\mathrm{R}$ diperoleh 0,05 artinya adanya hubungan positif yang signifikan antara keterampilan sosial terhadap komitmen organisasi pengurus UKK-KOPMA UIN Antasari Banjarmasin periode 2018/2019.

Penelitian ini juga membuat suatu kategorisasi untuk setiap variabel, tujuannya agar menempatkan individu atau subjek penelitian ke dalam kelompok-kelompok yang posisi berjenjang menurut suatu kontinum berdasarkan atribut yang diukur. Berikut di bawah ini tabel yang memaparkan tentang keterampilan sosial terhadap komitmen organisasi pengurus UKK-KOPMA UIN Antasari Banjarmasin periode 2018/2019.

Tabel 2

Tingkat Keterampilan Sosial

\begin{tabular}{ccc}
\hline Norma & Frekuensi & Presentase \\
\hline Tinggi & 3 & $7.3 \%$ \\
Sedang & 29 & $70.7 \%$ \\
Rendah & 9 & $22 \%$ \\
\hline
\end{tabular}

Berdasarkan tabel 2 di atas diketahui bahwa tingkat keteram pilan sosial pengurus UKKKOPMA UIN Antasari Banjarmasin periode 2018/2019 dengan kategori tinggi sebesar 7.3\% (3 orang), sedang $70.7 \%$ (29 orang), dan rendah $22 \%$ (9 orang).

Tabel 3

Tingkat Komitmen Organisasi

\begin{tabular}{ccc}
\hline Norma & Frekuensi & Persentase \\
\hline Tinggi & 6 & $14.6 \%$ \\
Sedang & 29 & $70.7 \%$
\end{tabular}


Berdasarkan tabel 3 di atas diketahui bahwa tingkat komitmen organisasi pengurus UKK-KOPMA UIN Antasari Banjarmasin periode 2018/2019 dengan kategori tinggi sebesar $14.6 \%$ (6 orang), rendah $14.6 \%$ (6 orang) dan sedang 70.7\% (29 orang).

\section{Pembahasan}

Berdasarkan hasil analisis tentang pengaruh keterampilan sosial terhadap komitmen organisasi dengan menggunakan SPSS statistic 22 for windows nilai signifikan pada uji regresi sederhana lebih kecil dari 0.05, yaitu 0.048. Artinya variabel keterampilan sosial memiliki pengaruh terhadap variabel komitmen organisasi. Jadi, tinggi rendahnya keterampilan sosial pengurus organisasi UKK-KOPMA UIN Antasari berpengaruh terhadap komitmen organisasinya.

Dilihat dari hasil analisis tersebut, pengaruh ketampilan sosial terhadap komitmen organisasi hanya sebesar $9.6 \%$ dan $90.4 \%$ sisanya dipengaruhi oleh variabel lain. Tingkat hubungan antara keterampilan sosial dengan komitmen organisasi terletak pada kategori rendah. Hal ini dibuktikan dengan nilai signifikan 0.311 yang terletak antara 0.20-0.399. Jadi, dapat disimpulkan bahwa keterampilan sosial berpengaruh terhadap komitmen organisasi dengan pengaruh yang tidak begitu tinggi.

Keterampilan sosial adalah kecerdasan emosional yang dikemukakan oleh Daniel Goleman. Menurutnya, keterampilan sosial adalah sebuah cara dalam berinteraksi dengan orang lain. Sebuah kemampuan untuk membangun sebuah interaksi dengan orang lain (Goleman, 2019). Ada beberapa penelitian tentang pengaruh kecerdasasn emosional terhadap komitmen. Namun, jarang ditemukan tentang aspek mana yang paling berpengaruh terhadap komitmen organisasi tersebut. Kemudian, ada salah satu penelitian yang menjelaskan dengan lengkap pengaruh kecerdasan emosional terhadap komitmen organisasi. Penelitian tersebut dilakukan oleh Efendi dan Sutanto yang berjudul pengaruh faktor-faktor kecerdasan emosional pemimpin terhadap komitmen organisasional karyawan Universitas Kristen Petra. Pada penelitian tersebut dijelaskan bahwa hanya 3 aspek yang berpengaruh terhadap komitmen 
organisasi. Aspek-aspek tersebut adalah keterampilan sosial, motivasi diri serta kontrol diri. Pengaruh yang paling besar adalah motivasi diri dan yang paling kecil pengaruhnya adalah keterampilan sosial (Efendi \& Sutanto, 2013).

Motivasi diri adalah kemampuan untuk mendorong diri sendiri agar menjadi lebih baik dengan kesiapan mental yang bagus, emosi terkendali dan pikiran positif untuk melangkah maju (Efendi \& Sutanto, 2013). Islam juga menerangkan bahwa pengaruh paling besar dalam berkomitmen adalah motivasi diri. Hal ini tertulis dalam Q.S. ar-Ra'ad/13: 11 yang artinya:

"Bagi manusia a da malaikat-malaikat yang selalu mengikutinya bergiliran, di muka dan di belakangnya, mereka menjaganya atas perintah Allah. Sesungguhnya Allah tidak merubah keadaan sesua tu kaum sehingga mereka merubah keadaan yang a da pada diri mereka sendiri. Dan apabila Allah menghendaki keburukan terhadap sesua tu kaum, maka tak ada yang dapat menolaknya; dan sekali-kali tak ada pelindung bagi mereka selain Dia."

Menurut ayat ini, kalimat yang menjadi patokan tentang motivasi diri adalah kalimat “Sesungguhnya Allah tidak merubah keadaan sesuatu kaum sehingga mereka merubah keadaan yang ada pada diri mereka sendiri". Kalimat tersebut menerangkan bahwa untuk melakukan sesuatu hal yang diinginkan, maka perlu dorongan yang kuat dalam melakukan hal tersebut. Dorongan tersebut merupakan anugrah dari Allah Swt. agar dapat bertindak dan mengendalikan diri sendiri, tetapi masih dalam naungan Allah (Hamka, 2015). Jadi, orang yang motivasi dirinya tinggi, maka akan berkomitmen terhadap apa yang diperintahkan oleh Allah SWT.

Pada firman Allah tersebut, ada juga pembahasan mengenai perubahan sosial. Hal ini dipahami dari kalimat ( قَّوم )yang berarti masyarakat. Masyarakat yang berawal dari pemikiran atau tingkah laku individu yang diterima dan menyebar di masyarakat, lalu sedikit demi sedikit masyarakat tersebut mengikuti pemikiran dan tingkah laku individu tadi (Hamka, 2015). Menurut teori Goleman ini ada hubungannya juga dengan keterampilan sosial pada aspek mengatur kelompok (Goleman, 2019). Jadi, orang yang memiliki motivasi diri, maka akan bertingkah laku sesuai dengan makna hidupnya, kemudian tingkah laku tersebut akan menyebar di masyarakat. Secara tidak langsung mengatur kelompok dalam masyarakat.

Walaupun aspek kecerdasan emosional yang paling berpengaruh terhadap komitmen organisasi adalah motivasi diri, namun aspek keterampilan sosial juga tidak bisa dianggap 
biasa. Ada beberapa ayat Alquran yang menerangkan tentang keterampilan sosial, kemudian pada ayat tersebut menerangkan juga tentang komitmen. Ayat-ayat tersebut adalah Q.S. anNisa/4: 1 yang artinya:

"Hai sekalian manusia, bertakwalah kepada Tuhan-mu yang telah menciptakan kamu dari seorang diri, dan dari padanya Allah menciptakan isterinya; dan dari pada keduanya Allah memperkembang biakkan laki-laki dan perempuan yang banyak. Dan bertakwalah kepada Allah yang dengan (mempergunakan) nama-Nya kamu saling meminta satu sama lain, dan (peliharalah) hubungan silaturrahim. Sesungguhnya Allah selalu menjaga dan mengawasi kamu."

Firman Allah di atas menjelaskan bahwa manusia diperintahkan untuk berkomitmen dalam taqwa. Setelah itu, ada penjelasan tentang keterampilan sosial, yaitu hubungan silaturahim yang tidak boleh putus. Hal ini terdapat pada kalimat yang artinya "dari seorang diri" (Shihab, 2011). Jadi, seluruh manusia diperintahkan Allah untuk bertaqwa dengan memperhatikan bahwa di antara manusia satu dengan manusia lain memiliki hubungan sosial, sehingga diwajibkan pula untuk saling mengenal. Hal ini diperkuat oleh ayat berikutnya yang menerangkan tentang keterampilan sosial dan komitmen organisasi, yaitu pada Q.S. alHujurat/49: 13 yang artinya:

"Hai manusia, sesungguhnya Kami menciptakan kamu dari seorang laki-laki dan seorang perempuan dan menjadikan kamu berbangsa-bangsa dan bersuku-suku supaya kamu saling kenalmengenal. Sesungguhnya orang yang paling mulia diantara kamu disisi Allah ialah orang yang paling takwa diantara kamu. Sesungguhnya Allah Maha Mengetahui lagi Maha Mengenal."

Pada firman Allah di atas, menerangkan perlunya saling mengenal antara satu dengan yang lain. Hal ini terdapat pada kalimat yang artinya "supaya kamu saling kenal-mengenal". Ketika seseorang saling kenal satu sama lain, maka peluang untuk saling memberi manfaat akan terbuka lebar. Manfaat yang didapatkan berupa pelajaran serta pengalaman dari pihak lain untuk meningkatkan ketaqwaan kepada Allah Swt. Upaya untuk melakukan hal tersebut berkaitan dengan keterampilan sosial seseorang. Kenal mengenal tidak akan terjadi tanpa ada keterampilan sosial. Kemudian tanpa saling mengenal, pelajaran dan pengalaman dari seseorang bahkan bekerja sama tidak akan terjadi (Shihab, 2011).

Selain itu, pernyataan tersebut juga dikuatkan oleh hasil wawancara responden setelah mereka mengisi angket. Hasil wawancara tersebut adalah keinginan berada pada organisasi untuk meningkatkan kemampuan dalam diri seperti cara berkomunikasi, kemudian responden 
menyatakan bahwa organisasi tersebut sangat cocok dengan minat yang dimiliki. Selain itu, responden merasa bertanggung jawab dengan organisasi dan tidak etis, jika keluar organisasi dengan alasan yang tidak jelas. Selanjutnya, ada pengaruh kecil yang membuat mereka tetap di organisasi tersebut, yaitu hubungan sosial yang erat dan rasa pertemanan yang kuat, sehingga menjadikan pengurus di dalam organisasi tersebut seperti keluarga. Para pengurus juga memiliki keinginan untuk berteman dan menjaga hubungan baik bersama orang yang berada di organisasi.

Berdasarkan pembahasan di atas, dapat disimpulkan bahwa keterampilan sosial merupakan aspek dari kecerdasan emosional yang dapat mempengaruhi secara positif terhadap komitmen organisasi. Menurut analisis besar pengaruh keterampilan sosial terhadap komitmen organisasi adalah $9.6 \%$ dan kategori hubungan antara keterampilan sosial dan komitmen organisasi adalah rendah, yaitu 0.311 pada rentang antara 0.20-0.399. Hal ini membuktikan bahwa aspek terkecil pengaruhnya dari kecerdasan sosial terhadap komitmen organisasi adalah keterampilan sosial. Walau begitu, pengaruh keterampilan sosial juga perlu diperhitungkan, karena ada beberapa ayat Alquran yang menjelask an hubungan tersebut dengan komitmen organisasi dan bukti empiris yang berupa wawancara terhadap responden.

\section{Kesimpulan}

Berdasarkan hasil penelitian di atas dapat disimpulkan bahwa terdapat pengaruh positif yang signifikan atau ada pengaruh antara keteram pilan sosial terhadap komitmen organisasi pengurus UKK-KOPMA UIN Antasari Banjarmasin periode 2018/2019. Hal ini dibuktikan dengan nilai koefisien determinasi ( $R$ square) sebesar 0.096 menunjukkan bahwa $9.6 \%$ dari varians komitmen organisasi dapat dijelaskan oleh perubahan dalam variabel keterampilan sosial. Sedangkan $90.4 \%$ sisanya dijelaskan oleh faktor lain diluar model. Kemudian nilai signifikansi variabel keterampilan sisoal terhadap komitmen organisasi $0,048<0,05$, hal ini menyatakan bahwa hipotesis kerja (H1) diterima dan hipotesis nol (H0) ditolak. Jadi, dapat disimpulkan bahwa keterampilan sosial yang dimiliki oleh pengurus UKK-KOPMA UIN Antasari Banjarmasin periode 2018/2019 dapat mempengaruhi komitmen organisasinya. 
Tingkat keterampilan sosial pengurus organisasi UKK-KOPMA UIN Antasari Banjarmasin berkategori tinggi yaitu berjumlah 3 orang (1 orang laki-laki dan 2 orang perempuan), sedang 29 orang (11 laki-laki dan 18 perempuan) dan rendah 9 orang (3 laki-laki dan 6 perempuan). Pernyataan tersebut terbukti dari analisis data variabel keterampilan sosial menggunakan SPSSS tatistic 22 for Windows. Hasil yang didapat adalah persentase keterampilan sosial pada kategori tinggi sebesar 7.3\%. Kategori sedang sebesar 70.7\%. Kemudian, yang terakhir adalah kategori rendah sebesar $22 \%$.

Tingkat komitmen organisasi pengurus UKK-KOPMA UIN Antasari Banjarmasin berkategori berkategori tinggi yaitu berjumlah 6 orang ( 3 orang laki-laki dan 3 orang perempuan), sedang 29 orang (10 laki-laki dan 19 perempuan) dan rendah 6 orang (2 laki-laki dan 4 perempuan). Pernyataan tersebut terbukti dari analisis data variabel komitmen organisasi menggunakan SPSS statistic 22 for windows. Hasil yang didapat adalah persentase komitmen organisasi pada kategori tinggi sebesar 14.6\%. Kategori sedang sebesar 73.2\%. Kemudian, yang terakhir adalah kategori rendah sebesar $12.2 \%$.

\section{Saran}

Berdasarkan paparan hasil dari penelitian, terdapat beberapa saran yang nantinya bisa saja di jadikan masukan sebagai pelengkap pada penelitian yang selanjutnya. Serta juga sebagai bahan masukan untuk seluruh pengurus organisasi UKK-KOPMA UIN Antasari Banjarmasin atau pun pengurus organisasi lainnya yang ada di seluruh dunia yang membaca jurnal ini bahwa dengan meningkatkan keterampilan sosial, maka komitmen organisasi juga dapat ditingkatkan pula.

Hasil penelitian ini menunjukkan bahwa keterampilan sosial pengurus organisasi UKKKOPMA UIN Antasari Banjarmasin berkategori sedang. Meskipun begitu, perlu juga untuk ditingkatkan lagi agar menggapai keterampilan yang lebih baik dalam bersosialisasi. Keterampilan sosial yang baik dapat dengan mudah beradaptasi di lingkungan apapun, menjin hubungan sosial dan menjaganya. Hal ini dipelukan agar tugas di organisasi dapat dikerjakan dengan mudah. 
Pada variabel komitmen organisasi pengurus UKK-KOPMA UIN Antasari Banjarmasin juga berada pada kategori sedang. Hal ini sudah bagus, akan tetapi peningkatan pada komitmen itu juga diperlukan agar para pengurus dapat bekerja dengan maksimal demi organisasinya. Hal ini akan mendorong kemajuan organisasi dan memberikan kenyamanan terhadap pengurusnya juga.

Bagi peneliti selanjutnya, diharapkan bisa meneliti lebih dalam tentang keterampilan sosial dan komitmen organisasi. Bisa dengan menambah atau mengganti variabel bebas yang mendukung seperti motivasi diri. Bisa juga mengganti metode penelitian ini menjadi kualitatif, sehingga mendapatkan hasil yang lebih mendalam tentang keterampilan sosial dan komitmen organisasi.

\section{Referensi}

Asmuni, A. (2018). Pengaruh Sistem Akuntansi Terhadap Kemampuan Mahasiswa Pendidikan Akuntansi Untuk Menjadi Pemimpin Dalam Organisasi. Jurnal Neraca: Jurnal Pendidikan dan Ilmu Ekonomi Akuntansi, 2(2), 40-48.

Efendi, V. A., \& Sutanto, E. M. (2013). Pengaruh Faktor-Faktor Kecerdasan Emosional Pemimpin terhadap Komitmen Organisasional Karyawan Universitas Kristen Petra. AGORA, Vol. 1(No. 1), 1-7.

Ghoniyah, N., \& Masurip. (2011). Peningkatan Kinerja Karyawan melalui Kepemimpinan, Lingkungan Kerja dan Komitmen. Jurnal Dinamika Manajemen, 2(2), 118-129.

Goleman, D. (2019). Emotional Intelligence (Kecerdasan Emosional) Mengapa EI Lebih Penting daripada IQ (Cet. XX, Cet. XX) [Computer software]. PT. Gramedia Pustaka Utama.

Hamka. (2015). Tafsir Azhar: Vol. Jilid 5 (Cet. 1). Gema Insani.

Kurniawan, A. (2015). Pengaruh Komitmen Organisasi terhadap Organizational Citizenship Behapior (OCB) PT. X Bandung. Jurnal Manajemen, Vol. 15(No. 1), 95-118.

Kurniawati, J. (2016). Literasi Media Digital Mahasiswa Universitas Muhammadiyah Bengkulu (Survei Tingkat Literasi Media Digital pada Mahasiswa Universitas Muhammadiyah Bengkulu Ditinjau dari Aspek Individual Competence). Komunikator, 8(2), 51-66.

Machmud, H. (2013). Pengaruh Pola Asuh dalam Membentuk Keterampilan Sosial Anak. AlMunzir, Vol. 6(No. 1), 130-138.

Setiawan, A. (2011). Analisis Pengaruh Affective Commitment, Continuance Commitment, dan Normative Commitment terhadap Kinerja [Skripsi]. Universitas Diponegoro.

Shihab, M.Q. (2011). Tafsir Al-Misbah (Pesan, Kesan dan Keserasian Al-Qur'an) (Cet. IV, Cet. IV, Vol. 2). Lentera Hati.

Shihab, M.Q. (2011). Tafsir Al-Misbah (Pesan, Kesan dan Keserasian Al-Qur'an) (Cet. IV, Cet. IV, Vol. 12). Lentera Hati.

Sugiyono. (2015). Metode Penelitian Pendidikan (Pendekatan Kuantitatif, Kualitatif, dan RED). CV. Alfabeta. 
Sutanto, E. M., \& Gunawan, C. (2013). Kepuasan Kerja, Komitmen Organisasional dan Turnover Intentions. Jurnal Mitra Ekonomi dan Manajemen Bisnis, 4, 76-88.

Widyastuti, D. T. (2011). Pelatihan Dasar Untuk Meningkatkan Keterampilan Sosial Siswa Sekolah Dasar (Studi Pada SDN 5 Bangsri Jepara) [Skripsi]. Universitas Negeri Semarang.

\begin{tabular}{|l|l|l|l|l|}
\hline Submit & Review & Revisi & Diterima & Publish \\
\hline $16-10-2020$ & - & - & $30-03-2021$ & $22-04-2021$ \\
\hline
\end{tabular}

Muhammad Hasan Amin, Ahmad Suriadi dan Shanty Komalasari

Program Studi Psikologi Islam

Fakultas Ushuluddin dan Humaniora

Universitas Islam Negeri Antasari (UIN) Banjarmasin

Email : muhammadhasanamin.mha@gmail.com 